\title{
Occurrence of Dioctophyme renale larvae (Goeze, 1782) (Nematoda: Enoplida) in a new host from southern Brazil
}

\author{
Novo hospedeiro de larvas de Dioctophyme renale (Goeze, 1782) (Nematoda: Enoplida) \\ no extremo sul do Brasil
}

Carolina Silveira Mascarenhas ${ }^{1 *}$; Julia Veiga Pereira ${ }^{1}$; Gertrud Müller ${ }^{1}$

\begin{abstract}
${ }^{1}$ Laboratório de Parasitologia de Animais Silvestres - LAPASIL, Instituto de Biologia - IB, Universidade Federal de Pelotas - UFPel, Pelotas, RS, Brasil
\end{abstract}

Received May 11, 2018

Accepted July 10, 2018

\begin{abstract}
Dioctophymatosis is caused by the giant kidney worm Dioctophyme renale which occurs in dogs, cats, and wild mammals. In Brazil, the disease has been diagnosed in dogs from several states around the country. In the present study, the occurrence of $D$. renale larvae in snakes from southern of Brazil is reported. Three specimens of Philodryas patagoniensis (Serpentes: Dipsadidae) (common names in Brazil: "parelheira", "papa-pinto") roadkill in the county of Capão do Leão, State of Rio Grande do Sul, southern Brazil, were necropsied. Two third-stage larvae of $D$. renale were found in the coelomic cavity of $P$. patagoniensis. This study reveals a new host for $D$. renale larvae in the southern region of the State of Rio Grande do Sul, Brazil. This particular geographic area of the country has stood out as several cases of $D$. renale infection have been reported in a number of vertebrates from this region including domestic dogs and cats and wild animals such as carnivores, fish, and freshwater turtles.
\end{abstract}

Keywords: Giant kidney worm, third-stage larvae, snake, Philodryas patagoniensis, "parelheira”, "papa-pinto".

\section{Resumo}

Dioctophyme renale, verme gigante do rim, parasita cáes, gatos e mamíferos silvestres, sendo que no Brasil, a dioctofimatose canina vem sendo diagnosticada em diversos estados brasileiros. $\mathrm{O}$ estudo tem por objetivo registrar larvas de D. renale parasitando serpente no extremo sul do Brasil. Nesse contexto, foram examinados três espécimes de Philodryas patagoniensis (Serpentes: Dipsadidae) encontradas mortas após atropelamento em uma estrada do município de Capão do Leão, Rio Grande do Sul (RS). Duas larvas de terceiro estágio de $D$. renale foram encontradas na cavidade celomática de $P$. patagoniensis, a qual representa um novo hospedeiro para larvas de $D$. renale na regiáo sul do RS, a qual vem se destacando devido aos diversos registros do parasito em cáes e gatos domésticos, bem como animais silvestres (carnívoros, peixes, quelônios).

Palavras-chave: Verme gigante do rim, larva de terceiro estágio, serpente, Philodryas patagoniensis, parelheira, papa-pinto.

\section{Introduction}

Dioctophyme renale (Goeze, 1782) infection occurs in many countries worldwide including domestic dogs and cats and also in wild carnivores such as canids and mustelids. The preferred organ site of $D$. renale infection is the right kidney. However, there are several reports describing the presence of the nematode in the peritoneal cavity and, less frequently in both kidneys from the same animal and in other sites throughout the body (ANDERSON,

\footnotetext{
*Corresponding author: Carolina Silveira Mascarenhas. Laboratório de Parasitologia de Animais Silvestres, Departamento de Microbiologia e Parasitologia, Instituto de Biologia, Universidade Federal de Pelotas - UFPel, Campus Universitário, CP 354, CEP 96010-900, Pelotas, RS, Brasil. e-mail: phrybio@hotmail.com
}

2000). This parasitic disease is of public health interest since it is a zoonosis and therefore poses a risk to humans. In Asian countries, there are case reports of dioctophymatosis in humans in which $D$. renale was found in the skin and the kidneys of the affected individuals (HANJANI et al., 1968; URANO et al., 2001; IGNJATOVIC et al., 2003; KATAFIGIOTIS et al., 2013; TOKIWA et al., 2014; NOROUZI et al., 2017). In Brazil, to date there is only one case of $D$. renale infection affecting a person in the state of Maranhăo (LISBOA, 1945).

The life cycle of the nematode involves freshwater organisms such as oligochaetes which are the intermediate hosts, fish, and anurans that play the role of paratenic hosts. These aquatic organisms may harbor the infective third-stage larva which is transmitted to 
mammalian definitive hosts along the food chain. Once in the final host, the worm migrates to the kidney and completes its life cycle. Third-stage larvae develop into adults, and the female starts laying eggs which are shed in the urine contaminating the environment (MACE \& ANDERSON, 1975; MEASURES \& ANDERSON, 1985).

In Brazil, larvae of $D$. renale have been found in anurans (PEDRASSANI et al., 2009), fish (ABDALLAH et al., 2012; MASCARENHAS et al., 2016), and freshwater turtles (MASCARENHAS \& MÜLLER, 2015; MASCARENHAS et al., 2017). Three of these cases of $D$. renale infection affecting aquatic organisms in Brazil (MASCARENHAS \& MÜLLER, 2015; MASCARENHAS et al., 2016; MASCARENHAS et al., 2017) originated from the southern region of the State of Rio Grande do Sul, where several cases of dioctophymatosis have been diagnosed in dogs (RAPPETI et al., 2017). The present report documents the occurrence of $D$. renale larvae in a previously unreported host from southern Brazil.

\section{Materials and Methods}

Three specimens of Philodryas patagoniensis (Girard, 1857) (Serpentes: Dipsadidae) (common names in Brazil: "parelheira", "papa-pinto") roadkill in the county of Capão do Leão, State of Rio Grande do Sul, southern Brazil, were necropsied. Sample collection was authorized by the Instituto Chico Mendes de Conservação da Biodiversidade (ICMBio/nº 38913).

At necropsy, the following organs from these snakes were examined individually: oral cavity, esophagus, stomach, small intestine, large intestine, heart, liver, lungs, kidneys, gonads, and coelomic cavity.

Larvae were fixed in AFA, stored in $70^{\circ}$ alcohol GL, and clarified with Amann lactophenol. Larvae of $D$. renale were morphologically identified according to Mace \& Anderson (1975) and Measures \& Anderson (1985).

Specimens were deposited in the Coleção de Helmintos do Laboratório de Parasitologia de Animais Silvestres (CHLAPASIL/UFPel, Pelotas, RS, Brazil, no 713). Photomicrographs were captured using an Olympus ${ }^{\circledR}$ BX 41 microscope with a camera. The software Adobe Photoshop ${ }^{\circledR}$ CS5 5 was used to prepare the images for publication.

\section{Results and Discussion}

One specimen of $P$. patagoniensis were parasitized by two third-stage larvae of $D$. renale (Figure 1). Larvae were reddish in color and were found encysted in the coelomic cavity of this snake. Measurements of male and female larvae of $D$. renale are given in Table 1.

Biserkov (1995) and Yildirimhan et al. (2007) reported the occurrence of larvae of Dioctophymatidae in snakes from Bulgaria and Turkey, where larvae of Eustrongylides excisus Jagerskiold, 1909 was reported in Natrix tessellata (Laurenti, 1768) (dice snake) and Natrix natrix (Linnaeus, 1758) (grass snake) (Natricidae). Morphological differentiation between third-stage larvae of $D$. renale and Eustrongylides spp. is made mainly by the position of the vulvar primordium in the female larvae. In female larvae of $D$. renale, the vulvar primordium is located near the intestinal-esophageal junction (MACE \& ANDERSON, 1975; MEASURES \& ANDERSON, 1985), whereas in female larvae of Eustrongylides spp. this structure lies close to the anal aperture (MEASURES, 1988). Figure 1C-D shows the vulvar primordium near the intestinal-esophageal junction in the female larva of $D$. renale found in the snake.

In the State of Rio Grande do Sul (RS), southern Brazil, third-stage larvae of $D$. renale have been found in the freshwater turtles, Trachemys dorbigni (Duméril \& Bibron, 1835) (D’Orbigny's slider, "tartaruga-tigre") and Phrynops hilarii (Duméril \& Bibron, 1835) (Hilaire's toadhead turtle) and in the catfish Hoplosternum littorale (Hancock, 1828). In the urban area of the city of Pelotas, south region of RS, which is located in the vicinity of the neighbor city Capáo do Leão, there are reports on the occurrence of larvae of $D$. renale in T. dorbigni (Emydidae) with a prevalence of $87.5 \%$ and mean intensity of infection of 13.9 larvae/host in 32 necropsied freshwater turtles (MASCARENHAS \& MULLER, 2015). The prevalence and mean intensity of infection in cases of parasitism by larvae of $D$. renale in $P$. hilarii (Chelidae) (MASCARENHAS et al., 2017) and $H$. littorale (Callichthyidae) (MASCARENHAS et al., 2016) were both low in comparison with those of T. dorbigni. It is worth mentioning that few specimens of $P$. hilarii e $H$. littorale were examined.

The life cycle of $D$. renale consists of complex trophic interactions in which mammalian definitive hosts are infected through ingestion of intermediate hosts (freshwater oligochaetes) or paratenic hosts (fish and anurans) which are infected with third-stage larvae of the nematode (MACE \& ANDERSON, 1975; MEASURES \& ANDERSON, 1985). In the Brazilian cities of Pelotas and Capão do Leão the adult stage of $D$. renale occurs in domestic dogs, cats (RAPPETI et al., 2017) and in the wild carnivores Galictis cuja (Molina, 1782) (lesser grisson) (PESENTI et al., 2012), Lontra longicaudis (Olfers, 1818)

Table 1. Measurements of male and female third-stage larvae of Dioctophyme renale (Enoplida: Dioctophymatidae) found in a naturally infected snake Philodryas patagoniensis (Girard, 1858) (Serpentes: Dipsadidae) from southern Brazil (measurements are expressed here as $\mathrm{mm}$ ).

\begin{tabular}{lcc}
\hline & male $(\mathbf{n}=\mathbf{1})$ & female $(\mathbf{n}=\mathbf{1})$ \\
\hline Body length & 12.63 & 13.785 \\
Pharynx length & 0.06 & 0.085 \\
$\begin{array}{l}\text { Distance of first row of papillae } \\
\text { to anterior extremity }\end{array}$ & 0.013 & 0.01 \\
$\begin{array}{l}\text { Distance of second row of } \\
\text { papillae to anterior extremity }\end{array}$ & 0.028 & 0.025 \\
$\begin{array}{l}\text { Distance of nerve ring to anterior } \\
\text { extremity }\end{array}$ & 0.125 & 0.125 \\
$\begin{array}{l}\text { Esophagus length } \\
\text { Esophagus \% of the total length }\end{array}$ & $33.65 \%$ & $31.92 \%$ \\
$\begin{array}{l}\text { Width at the } \\
\text { esophageal-intestinal junction }\end{array}$ & 0.27 & 0.27 \\
$\begin{array}{l}\text { Distance of vulvar primordium } \\
\text { to anterior extremity }\end{array}$ & - & \\
Rectum length & & \\
\hline
\end{tabular}



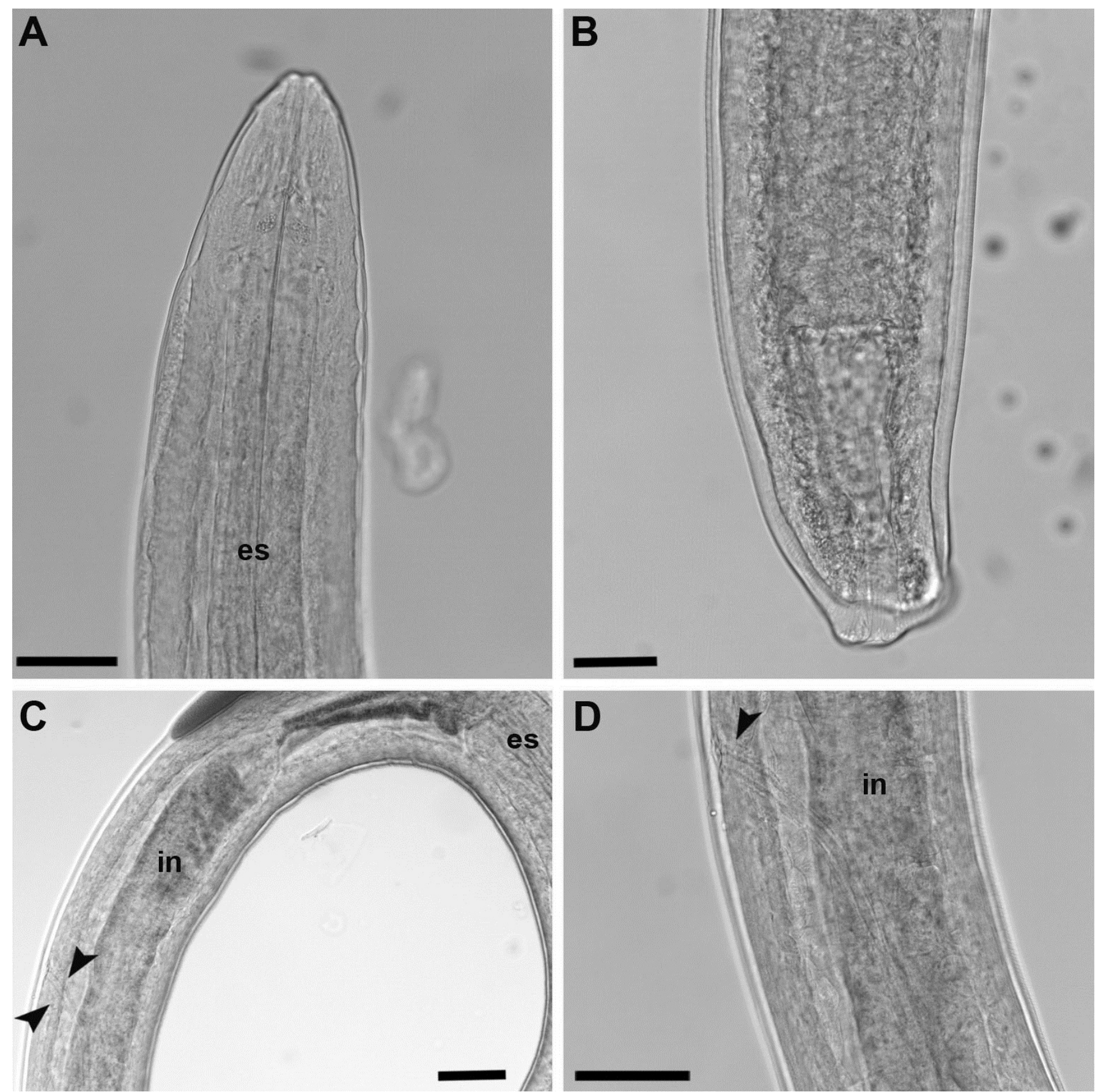

Figure 1. Third-stage larva of Dioctophyme renale parasite of Philodryas patagoniensis (Girard, 1858) (Serpentes: Dipsadidae) from southern Brazil. A - Anterior extremity of female larva (es - esophagus) (Bar $=60 \mu \mathrm{m})$. B - Posterior extremity of female larva (Bar $=62 \mu \mathrm{m})$. C - Vulvar primordium (arrows) of female larva near to junction esophagus-intestine (es - esophagus, in - intestine) $($ Bar $=95 \mu \mathrm{m}) . \mathbf{D}-\mathrm{Detail}$ of vulvar primordium (arrow) and intestine (in) of female larva $($ Bar $=95 \mu \mathrm{m})$.

(neotropical river otter) (Mustellidae) (ECHENIQUE et al., 2018), and Leopardus geoffroyi (d'Orbigny \& Gervais, 1844) (Felidae) (Geoffroy's cat) (TRINDADE et al., 2018).

The presence of larvae of $D$. renale in the snake $P$. patagonensis may be related to the feeding habit of this host which is a dietary generalist. Its diet includes include birds, amphibians, lizards, other species of snakes, and rodents (HARTMANN \& MARQUES, 2005; SAZIMA \& HADDAD, 1992; ROCHA \& VRCIBRADIC,
1998). Despite the fact that snakes have a broad, generalist diet, Pontes (2007) reported that the diet of $P$. patagonensis which live along the coast of the State of Rio Grande do Sul, southern Brazil, consists mostly of anuran amphibians. Interestingly, anurans are paratenic hosts of $D$. renale in Canada (MACE \& ANDERSON, 1975) and Brazil in the state of Santa Catarina (PEDRASSANI et al., 2009). In this context, the ocurrence of $D$. renale in snakes, freshwater turtles, and fish in our study area 
suggests that infective larvae of this nematode are transferred between different hosts that form the food web. Wild carnivores are the definitive hosts of this helminth and are at the top of the food chain. Potential paratenic hosts inhabit this geographic region and may contribute for the perpetutation of the life-cycle of this worm in wildlife.

The role of snakes, freshwater turtles, and fish as a source of infection for domestic dogs and maintenance of the life-cycle of the parasite in urban areas should be interpreted with caution, since these hosts must be ingested by the dogs for that occurs infection with the larvae. We should also consider the fact that it may be difficult for dogs to capture a sufficient number of vertebrate preys in urban areas in order to mantain effectively the life cycle of the helminth. However, we should not rule out the possibility that dogs may ingest freshwater turtles and snakes hit by cars in urban areas. Third-stage larvae of $D$. renale may be found in roadkill vertebrates hosts such as $P$. hilarii as described by Mascarenhas et al. (2017). Our findings corroborate those of previous research published by these authors. We should emphasize the fact that the presence of larvae of $D$. renale in fish, freshwater turtles, and snakes indicates that these vertebrates may be sentinel species for the occurrence of dioctophymatosis in our area. From 2010 to 2015, about 70 cases of canine dioctophymatosis were diagnosed in the city of Pelotas, State of Rio Grande do Sul, southern Brazil (RAPPETI et al., 2017).

The results of the present study show that the south region of the State of Rio Grande do Sul is an important area of occurrence for $D$. renale infection in animals. In this scenario of several hosts that harboring the nematode, remains a gap to be known: the essential link that allows the continuity of the cycle, the intermediate host. The freshwater oligochaete Lumbriculus variegatus (Müller, 1774) (Lumbriculidae: Clitellata) was identified in North America as the intermediate host of $D$. renale larvae (MACE \& ANDERSON, 1975). However, in South America the intermediate host in which the third-stage infecting larvae develop remains unknown. Lumbriculus variegatus has been found in Patagonia, Argentina (MISERENDINO, 2007) and in the State of Minas Gerais, southeast Brazil (MARCHESE et al., 2015). However, we should consider the hypothesis that other species of oligochaetes may also act as intermediate hosts of the worm in South America.

Dioctophymatosis is a parasitic disease that may threaten animal and public health. Additional studies should be conducted to investigate the life cycle of $D$. renale in our area. Further research should be carried out to determine the epidemiological aspects of the transmission and maintainance of the life cycle of this nematode in urban areas.

\section{Acknowledgements}

Special thanks to Marco Antônio Afonso Coimbra, Ana Rui, Thainá Dutra Vieira, and Soliane Carra Perera for their assistance. This work was supported by CAPES (Coordenação de Aperfeiçoamento do Pessoal de Nível Superior, process number 32/2010).

\section{References}

Abdallah VD, Azevedo RK, Carvalho ED, Silva RJ. New hosts and distribution records for nematode parasites of freshwater fishes from São Paulo, Brazil. Neotrop Helminthol 2012; 6(1): 43-57.

Anderson RC. Nematode parasites of vertebrates: their development and transmission. London: CABI International; 2000. http://dx.doi.org/10. 1079/9780851994215.0000.

Biserkov VY. New records of nematodes and acanthocephalans from snakes in Bulgaria. Dokl Bulg Akad Nauk 1995; 48(11-12): 87-89.

Echenique JVZ, Soares MP, Mascarenhas CS, Bandarra PM, Quadros P, Driemeier D, et al. Lontra longicandis (Olfers, 1818) de vida livre infectada por parvovirus canino e parasitada por Dioctophyme renale. Pesq Vet Bras 2018; (in press)

Hanjani AA, Sadighian A, Nikakhtar B, Arfaa F. The first report of human infection with Dioctophyma renale in Iran. Trans $R$ Soc Trop Med Hyg 1968; 62(5): 647-648. http://dx.doi.org/10.1016/0035-9203(68)901144. PMid:4236800.

Hartmann P, Marques OAV. Diet and habitat use of two sympatric species of Philodryas (Colubridae) in south Brazil. Amphib-Reptil 2005; 26(1): 25-31. http://dx.doi.org/10.1163/1568538053693251.

Ignjatovic I, Stojkovic I, Kutlesic C, Tasic S. Infestation of the human kidney with Dioctophyma renale. Urol Int 2003; 70(1): 70-73. http:// dx.doi.org/10.1159/000067695. PMid:12566820.

Katafigiotis I, Fragkiadis E, Pournaras C, Nonni A, Stravodimos KG. A rare case of a 39 year old male with a parasite called Dioctophyma renale mimicking renal cancer at the computed tomography of the right kidney. Parasitol Int 2013; 62(5): 459-460. http://dx.doi.org/10.1016/j. parint.2013.06.007. PMid:23811203.

Lisboa A. Estrongilose renal humana. Bras Med 1945; 11: 101-102.

Mace TF, Anderson RC. Development of the giant kidney worm, Dioctophyma renale (Goeze, 1782) (Nematoda: Dioctophymatoidea). Can J Zool 1975; 53(11): 1552-1568. http://dx.doi.org/10.1139/z75190. PMid: 127653

Marchese M, Santos M, Lima JS, Pamplin P. First record of introduced species Lumbriculus variegatus Müller, 1774 (Lumbriculidae, Clitellata) in Brazil. BioInv Rec 2015; 4(2): 81-85. http://dx.doi.org/10.3391/ bir.2015.4.2.02.

Mascarenhas CS, Henzel ABD, Corrêa F, Robaldo RB, Müller G. Thirdstage larvae of Dioctophyme renale (Goeze, 1782) (Nematoda: Enoplida) in Hoplosternum littorale (Hancock, 1828) (Siluriformes: Callichthyidae) from Southern Brazil. Neotrop Helminthol 2016; 10(1): 135-138.

Mascarenhas CS, Henzel ABD, Müller G. Larvae of Dioctophyme renale (Goeze, 1782) (Nematoda: Enoplida) and Contracaecum sp. (Nematoda: Anisakidae) in freshwater turtles (Testudines: Chelidae) from southern Brazil. Neotrop Helminthol 2017; 11(1): 61-67.

Mascarenhas CS, Müller G. Third-stage larvae of the enoplid nematode Dioctophyme renale (Goeze, 1782) in the freshwater turtle Trachemys dorbigni from southern Brazil. J Helminthol 2015; 89(5): 630-635. http:// dx.doi.org/10.1017/S0022149X14000364. PMid:24830883.

Measures LN, Anderson RC. Centrarchid fish as paratenic hosts of the giant kidney worm, Dioctophyma renale (Goeze, 1782), in Ontario, Canada. JWildl Dis 1985; 21(1): 11-19. http://dx.doi.org/10.7589/00903558-21.1.11. PMid:3157009. 
Measures LN. The development of Eustrongylides tubifex (Nematoda: Dioctophymatoidea) in oligochaetes. J Parasitol 1988; 74(2): 294-304. http://dx.doi.org/10.2307/3282459. PMid:3357121.

Miserendino ML. Macroinvertebrate functional organization and water quality in a large arid river from Patagonia (Argentina). Ann Limnol 2007; 43(3): 133-145. http://dx.doi.org/10.1051/limn:2007008.

Norouzi R, Manochehri A, Hanifi MA. Case report of human infection with Dioctophyma renale from Iran. Urol J 2017; 14(2): 3043-3045. PMid:28299768.

Pedrassani D, Hoppe EG, Tebaldi JH, Nascimento AA. Chaunus ictericus (Spix, 1824) as paratenic host of the giant kidney worm Dioctophyme renale (Goeze, 1782) (Nematoda: Enoplida) in São Cristóvão district, Três Barras county, Santa Catarina state, Brazil. Vet Parasitol 2009; 165(1-2): 74-77. http://dx.doi.org/10.1016/j.vetpar.2009.07.017. PMid:19664882.

Pesenti TC, Mascarenhas CS, Krüger C, Sinkoc AL, Albano APN, Coimbra MAA, et al. Dioctophyma renale (Goeze, 1782) Collet- Meygret, 1802 (Dioctophymatidae) in Galictis cuja (Molina, 1782) (Mustelidae) in Rio Grande do Sul, Brazil. Neotrop Helminthol 2012; 6(2): 301-305.

Pontes GMF. História natural de Philodryas patagoniensis (Serpentes: Colubridae) no litoral do Rio Grande do Sul, Brasil [tese]. Porto Alegre: Pontifícia Universidade Católica do Rio Grande do Sul; 2007.

Rappeti JCS, Mascarenhas CS, Perera SC, Müller G, Grecco FB, Silva LMS, et al. Dioctophyme renale (Nematoda: Enoplida) in domestic dogs and cats in the extreme south of Brazil. Rev Bras Parasitol Vet 2017; 26(1): 119-121. http://dx.doi.org/10.1590/s1984-29612016072. PMid:27925066.
Rocha CFD, Vrcibradic D. Reptiles as predators of vertebrates and as preys in a restinga habitat of southeastern Brazil. Cienc Cult 1998; 50(5): 364-368.

Sazima I, Haddad CFB. Répteis da Serra do Japi: notas sobre história natural. In: Morellato LPC (Org). História Natural da Serra do Japi: ecologia e preservação de uma área florestal no sudeste do Brasil. Campinas: Editora da Unicamp; 1992. p. 212-237.

Tokiwa T, Ueda W, Takatsuka S, Okawa K, Onodera M, Ohta N, et al. The first genetically confirmed case of Dioctophyme renale (Nematoda: Dioctophymatida) in a patient with a subcutaneous nodule. Parasitol Int 2014; 63(1): 143-147. http://dx.doi.org/10.1016/j.parint.2013.09.015. PMid:24095916.

Trindade MAC, Macedo MRP, Müller G. Dioctophyme renale (Nematoda: Dioctophymatidae) in Leopardus geoffroyi (Carnivora: Felidae) in the Neotropical region. Rev Bras Parasitol Vet 2018; 27(2): 223-225. http:// dx.doi.org/10.1590/s1984-29612017079. PMid:29466503.

Urano Z, Hasegawa H, Katsumata T, Toriyama K, Aoki Y. Dioctophymatid nematode larva found from human skin with creeping eruption. $J$ Parasitol 2001; 87(2): 462-465. http://dx.doi.org/10.1645/00223395(2001)087[0462:DNLFFH]2.0.CO;2. PMid:11318590.

Yildirimhan HS, Bursey CR, Goldberg SR. Helminth parasites of the grass snake, Natrix natrix, and the dice snake, Natrix tessellata (Serpentes: Colubridae), from Turkey. Comp Parasitol 2007; 74(2): 343-354. http:// dx.doi.org/10.1654/4285.1. 